\title{
Lithobius (Monotarsobius) tanagolus sp.n., a new lithobiid species (Chilopoda, Lithobiomorpha) from southern Siberia, with remarks on the closely related L. (M.) bolstii (Pocock, 1895)
}

\author{
Lithobius (Monotarsobius) tanagolus sp.n., новая костянка \\ (Chilopoda, Lithobiomorpha) из Юэкной Сибири, с замечаниями \\ о бцизком виде L. (M.) bolstii (Pocock, 1895)
}

\author{
G.Sh. Farzalieva \\ Г.Ш. Фарзалиева
}

Perm State University, Bukireva Street 15, Perm, Russia, 614990. E-mail: g.farzalieva@yandex.ru

Пермский государственный национальный исследовательский университет, ул. Букирева 15, Пермь 614990 Россия.

KEY WORDS: taxonomy, Lithobiidae, new species, southern Siberia, Far East of Russia.

КЛЮЧЕВЫЕ СЛОВА: таксономия, Lithobiidae, новый вид, Южная Сибирь, Дальний Восток России.

ABSTRACT. A new species, Lithobius (Monotarsobius) tanagolus sp.n., is described from southern Siberia, Russia. The new species shows no apomorphies, but is defined by a unique combination of characters. It seems to be the closest to L. (M.) holstii (Pocock, 1895), but the female of L. tanagolus sp.n. differs well from that of L. holstii by the presence of a distodorsal spine on the first gonopodal segment and the armament of the second and third gonopodal segments. A refined diagnosis of $L$. (M.) holstii is given and its distribution mapped.

How to cite this article: Farzalieva G.Sh. 2018. Lithobius (Monotarsobius) tanagolus sp.n., a new lithobiid species (Chilopoda, Lithobiomorpha) from southern Siberia, with remarks on the closely related $L$. $(M$. holstii (Pocock, 1895) // Arthropoda Selecta. Vol.27. No.1. P.22-30. doi: 10.15298/arthsel. 27.1.02

РЕЗЮМЕ. Описан новый вид литобиоморфной многоножки Lithobius (Monotarsobius) tanagolus sp.n. из Южной Сибири (Россия). Новый вид не имеет уникальных признаков, а отличается от близких видов комбинацией признаков. Кажется, он наиболее близок к L. (M.) holstii (Pocock, 1895), но самки L. tanagolus sp.n. хорошо отличаются от самок L. holstii присутствием дистодорсального шипа на первом членике гонопода самки, а также дорсальным вооружением второго и третьего члеников гонопода. Для L. holstii приводится уточненный диагноз и карта распространения.

\section{Introduction}

Monotarsobius Verhoeff, 1905 is a large subgenus of the genus Lithobius Leach, 1814. The world fauna of Monotarsobius contains ca 115 species or subspe- cies [Bonato et al., 2011; Ma et al., 2014a, b], of which 23 valid species are known from Russia [Zalesskaja, 1978; Farzalieva, Zalesskaja, 2003; Farzalieva, Esyunin, 2008; Danyi, Tuf, 2012; Zuev, 2017].

A collection of lithobiids from the Altai Republic, Russia, stored in the Zoological Museum of Moscow University (ZMMU), has yielded a new species of Monotarsobius. In addition, several specimens of this species have also been located in new material from the Kemerovo Region, Russia.

The new species belongs to the group of Monotarsobius species that show neither well-expressed secondary sexual characters in the male nor apomorphies, being distinguished by a unique combination of characters. Lithobius (Monotarsobius) tanagolus sp.n. seems to be particularly similar to L. (M.) holstii (Pocock, 1895), from Japan (Ashinoju). The objective of the present is to describe the new species, as well as refine the diagnosis and distribution of L. (M.) holstii.

\section{Material and methods}

The material underlying the present study was largely collected by S.I. Golovatch, A.V. Tanasevitch and A.L. Tikhomirova in the Altai Republic (Lake Teletskoye and the Altai Nature Reserve, southern Siberia), as well as by L.A. Trilikauskas in the Shorsky National Park, Kemerovo Region, Russia. Most of the material is currently deposited in the collections of the Zoological Museum of the Lomonosov Moscow State University, Moscow, Russia (ZMUM; curator: A.A. Schileyko) and the Perm State University, Perm, Russia (PSU; curator: G. Sh. Farzalieva).

Measurements. The total body length was measured from the fore margin of the cephalic plate to the posterior end of the postpedal tergite. Leg length was mea- 
sured excluding the length of the claw. Lengths are given as the minimum and maximum values. All measurements are given in millimeters $(\mathrm{mm})$.

The number of coxal pores on legs $12-15$ is presented in a formula where a sequence of Arabic numerals means the number of pores on these legs, respectively.

The terminology of the external anatomy follows Bonato et al. [2010]. The following abbreviations are used in the text and table: a - anterior, C - coxa, D dorsal; $\mathrm{F}$ - femur, $\mathrm{m}$ - median, $\mathrm{p}$ - posterior, $\mathrm{P}$ prefemur, $\mathrm{t}$ - trochanter, $\mathrm{T}, \mathrm{TT}$ - tergite, tergites, $\mathrm{Tf}$ forcipular tergite, $\mathrm{Ti}$ - tibia, $\mathrm{V}$ - ventral.

\section{Taxonomic part}

\section{Lithobius (Monotarsobius) tanagolus sp.n. Figs 1-14, 19, Map 1.}

DIAGNOSIS. A Lithobius (Monotarsobius) species with body $6.3-10.0 \mathrm{~mm}$ long, antennae composed of 17-21 articles, commonly $19+19 ; 7-11$ ocelli on each side on head, commonly $8-9$, arranged in 3 rows; Tömösváry's organ as large as nearest ocellus, $2+2$ forcipular coxosternal teeth and setiform porodonts; unipartite tarsi of legs 1-13, posterior angles of all tergites without triangular projections; number of coxal pores varying from 3 to 5 , commonly $4 ; 1^{\text {st }}$ gonopodal segment with $2+2$ coniform spurs and a single distodorsal spine; terminal claw tridentate; $\sigma^{7}$ with a poorly-expressed dorsal sulcus on Ti 15; in both sexes, legs 15 more densely setose ventrally than dorsally (Figs 4, 6-7).

TYPES. Holotype $q$ (ZMMU) Russia, Altai Republic, Lake Teletskoye, near Lake Chiri, $51^{\circ} 22^{\prime} \mathrm{N}, 87^{\circ} 50^{\prime} \mathrm{E}$, subalpine belt (= goltsy), 1750-2000 m a.s.1., 29-30.VII.1997, S.I. Golovatch \& A.V. Tanasevitch. Paratypes: $15 \mathrm{O}^{\top} \mathrm{O}^{\top}, 4$ 우 (ZMMU), $5 \mathrm{O}^{\top} \mathrm{O}^{\top}, 2$ 우 (PSU), together with holotype; $20^{7} \sigma^{7}, 2$ + +9 (ZMMU), same locality, upper timberline of Picea obovata and Pinus sibirica taiga, mainly near water, $1700-1750 \mathrm{~m}$ a.s.1., 29.VII.-1.VIII.1997; $11 \bigcirc^{7} \sigma^{7}, 6$ 우 (ZMMU), Lake Teletskoye, Altai Nature Reserve,
Chiri, upper reaches of Chiri River, Picea obovata and Pinus sibirica taiga forest, $1350 \mathrm{~m}$ a.s.1., 28-29.VII. and 2.VIII.1997, all leg. S.I. Golovatch \& A.V. Tanasevitch.

NON-TYPE MATERIAL. 2 (ZMMU), Altai Republic, Lake Teletskoye, near Artybash, $51^{\circ} 47^{\prime} \mathrm{N}, 87^{\circ} 14^{\prime} \mathrm{E}$, Picea obovata, Abies sibirica and Pinus sibirica taiga, 500-800 m a.s.1., 13-24.VII.1997; $50^{7} 0^{7}, 2$ 우 (PSU), same locality, high bog in Picea obovata, Abies sibirica and Pinus sibirica taiga forest, $800 \mathrm{~m}$ a.s.1., 20.VII. 1997, all leg. S.I. Golovatch \& A.V. Tanasevitch; $200^{7} \sigma^{7}, 18$ 우 (ZMMU), $10^{x}, 1$ ㅇ (PSU), Altai Republic, Altai Nature Reserve, litter, IX.1969, leg. A.L. Tikhomirova; $30^{7} 0^{7}, 7$ 우 (PSU), Kemerovo Area, Shorsky National Park, near Verkhniy Taymet, $52^{\circ}$ $29^{\prime} \mathrm{N}, 88^{\circ} 16^{\prime} \mathrm{E}$, Abies forest with Tilia, Pinus sibirica taiga with Vaccinium and Betula forest, 20.VII.-11.VIII.2016; 2 Pᄋ (ZMMU), Kemerovo Area, Biyskaya Griva Mt. Range, Pinus sibirica taiga 11.VIII.2016, all leg. L.A. Trilikauskas.

NAME. The species is a combined abbreviation named after Andrei V. Tanasevitch (an expert in Linyphiidae spiders), and Sergei I. Golovatch (an expert in Diplopoda) who collected the type material.

DESCRIPTION. Holotype + . Body ca $9.7 \mathrm{~mm}$ long, $1.2 \mathrm{~mm}$ wide (at T10); colour in alcohol yellow-brownish. Tergites: almost smooth, with short and long setae, $\mathrm{T} 15$ indistinct; posterior margin of TT1, 3, 5, 8, 10, 12 , 14 and intermediate $\mathrm{T}$ slightly sinuate, as in Fig 2; intermediate $\mathrm{T}$ slightly broadened, breadth/length ratio 1.04 (length $0.68 \mathrm{~mm}$, breadth $0.70 \mathrm{~mm}$ ). Cephalic plate: breadth/length ratio 1.02 (breadth $1.02 \mathrm{~mm}$, length $1.00 \mathrm{~mm}$ ); breadth/breadth ratio of cephalic plate and Tf 1.22 (breadth of Tf $0.83 \mathrm{~mm}$ ). Antennae short, reaching the middle of T5, composed of 19+19 short articles, first two slightly enlarged (Fig. 5). Ocelli: 8 on each side, dark, arranged in three rows; posterior and posterosuperior ocelli poorly distinguished in size from other seriate ocelli. Tömösváry's organ as large as nearest ocellus, rounded (Fig. 1). Forcipular coxosternite: dental margin slightly concave, with $2+2$ acute teeth and setiform porodonts, median diastema Vshaped; shoulders of coxosternite strongly sloping, as in Figs 3, 19.

Tarsal articulation of legs 1-13 indistinct, tarsi distinctly longer than tibiae. Legs 14 and 15 slightly incrassate, with glandular pores on lateral and ventral

Table. Plectrotaxy of Lithobius tanagolus sp.n., holotype. Brackets show the presence of an asymmetric spine in one of leg-pairs.

Таблица. Плектротаксия Lithobius tanagolus sp.n., голотип. В скобках обозначено асимметричное расположение шипов на одной из пар ног.

\begin{tabular}{|c|c|c|c|c|c|c|c|c|}
\hline \multirow{2}{*}{ Leg } & \multicolumn{4}{|c|}{ Ventral } & \multicolumn{4}{|c|}{ Dorsal } \\
\hline & $\mathbf{t}$ & $\mathbf{P}$ & $\mathbf{F}$ & $\mathbf{T i}$ & C & $\mathbf{P}$ & $\mathbf{F}$ & $\mathbf{T i}$ \\
\hline 1 & - & - & - & $\mathrm{m}$ & - & - & $\mathrm{a}$ & $\mathrm{a}$ \\
\hline 2 & - & - & $\mathrm{m}$ & $\mathrm{m}$ & - & - & $\mathrm{a} p$ & $a(p)$ \\
\hline $3-5$ & - & - & $\mathrm{m}$ & $\mathrm{m}$ & - & - & a p & a p \\
\hline 6 & - & - & (a)m & $\mathrm{m}$ & - & - & $\mathrm{ap}$ & a p \\
\hline $7-9$ & - & - & am & $\mathrm{m}$ & - & - & a $p$ & $\mathrm{a} p$ \\
\hline 10 & - & $\mathrm{mp}$ & $\operatorname{am}(p)$ & $\mathrm{am}$ & - & - & a $p$ & a $p$ \\
\hline 11 & - & $\mathrm{mp}$ & amp & $\mathrm{am}$ & - & $(a)(p)$ & a p & a p \\
\hline $12-13$ & - & $\mathrm{mp}$ & amp & am & - & amp & $\mathrm{p}$ & $\mathrm{p}$ \\
\hline 14 & $\mathrm{~m}$ & amp & $\mathrm{am}$ & - & - & amp & $\mathrm{p}$ & - \\
\hline 15 & $\mathrm{~m}$ & amp & $\mathrm{am}$ & - & $\mathrm{a}$ & amp & - & - \\
\hline
\end{tabular}




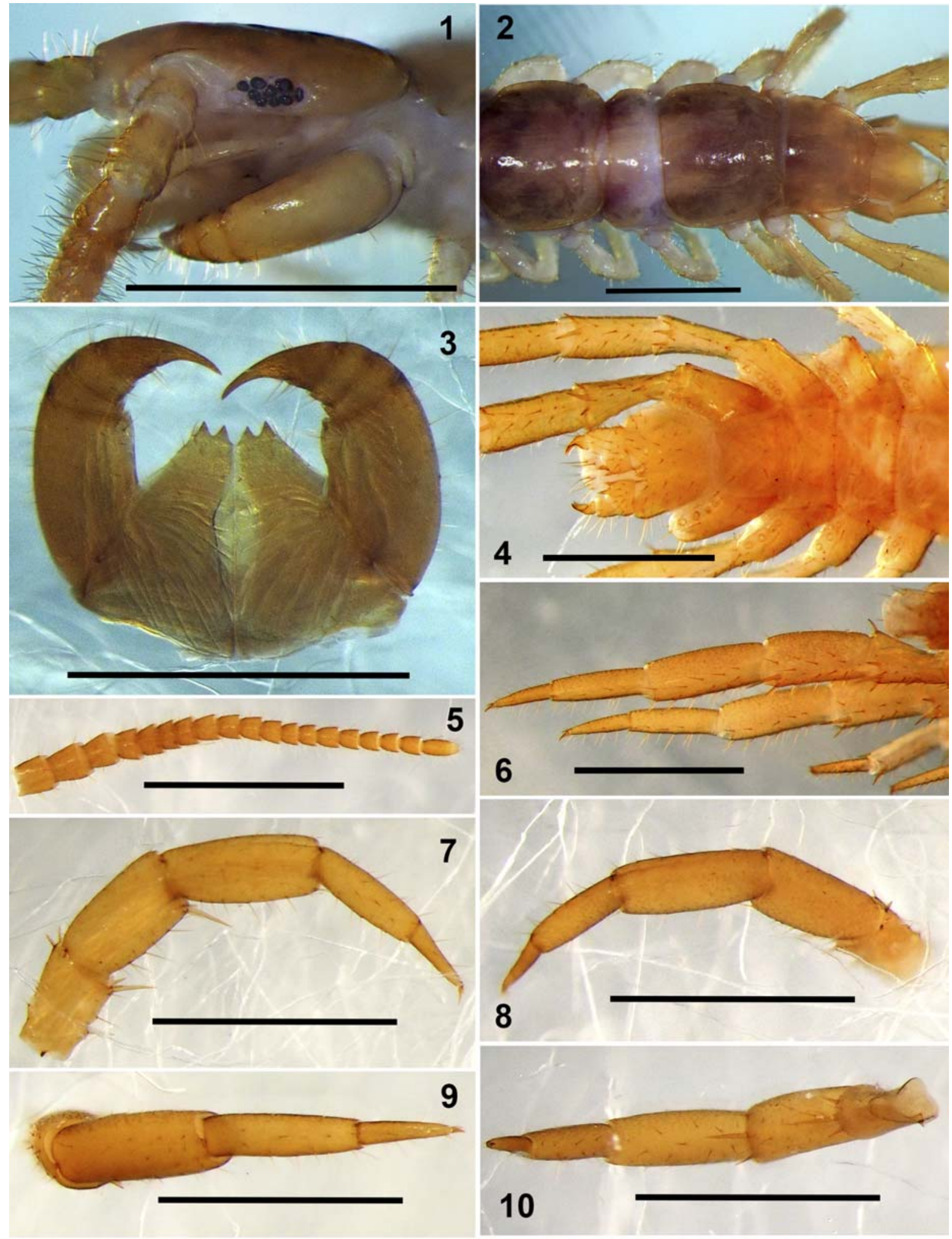

Figs 1-10. Lithobius tanagolus sp.n. $1-\mathrm{O}^{7}$ head, lateral view (paratype); $2-\mathrm{O}^{7}$ rear body fragment, dorsal view (paratype); $3-0+9$ forcipula, ventral view (non-type), $4-9$ rear body fragment, ventral view (non-type); $5-\sigma^{7}$ antenna, lateral view (non-type); $6-\sigma^{7}$ legs 15 , ventrolateral view (paratype); 7-10 - $\sigma^{7}$ leg 15, prolateral, retrolateral, dorsal and ventral views, respectively (non-type). Scale $1 \mathrm{~mm}$.

Рис. 1-10. Lithobius tanagolus sp.n. 1 - голова самца, латерально (паратип); 2 - задняя часть тела самца, дорсально (паратип); 3 - ногочелюсть самки, вентрально (нетиповой материал), 4 - задняя часть тела самки, вентрально (нетиповой материал); 5 - антенна самца, латерально (нетиповой материал); 6 - нога 15 самца, вентролатерально (паратип); 7-10 — нога 15 самца, пролатерально, ретролатерально, дорсально и вентрально, соответственно (нетиповой материал). Масштаб 1 мм. 

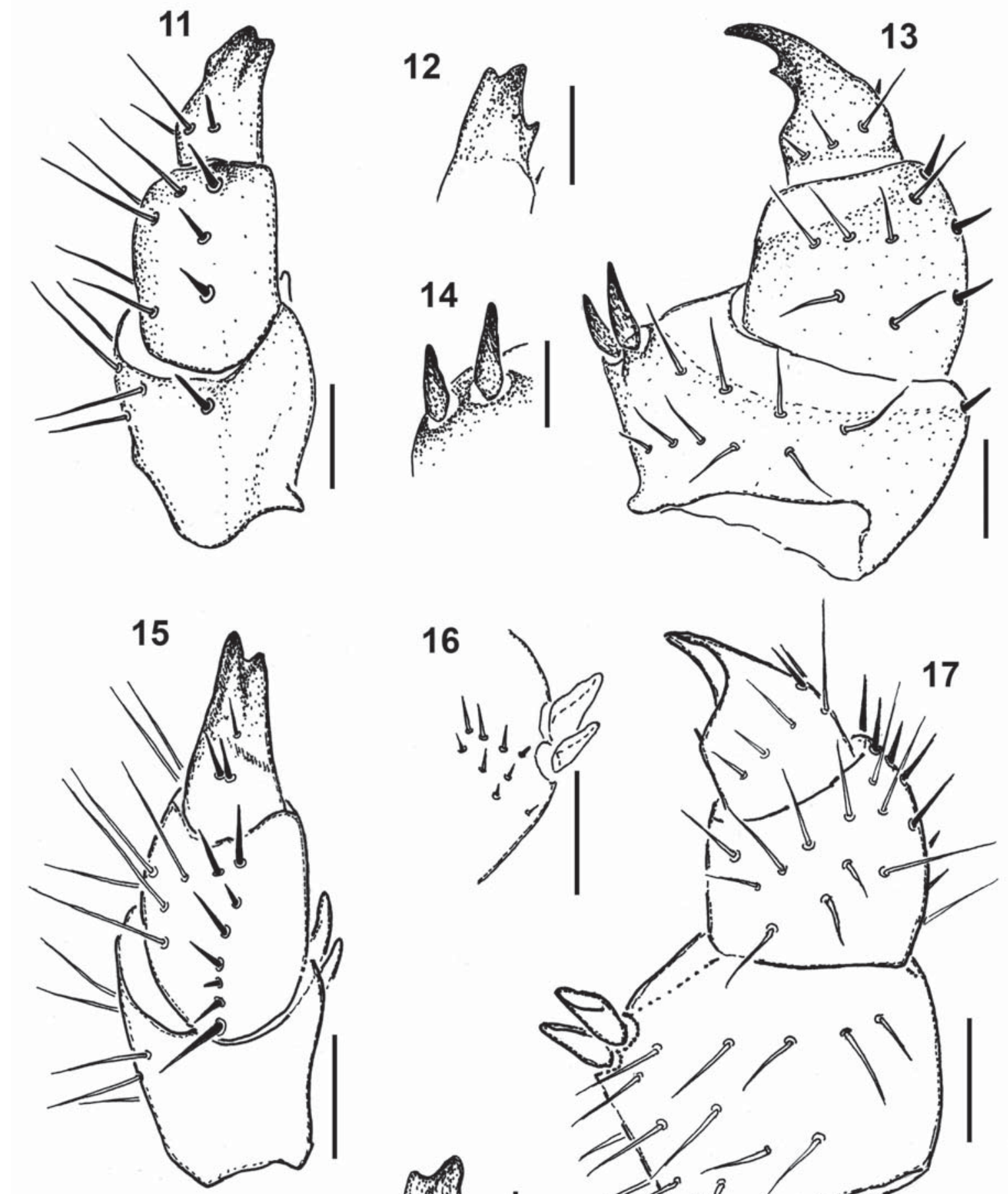

16

18
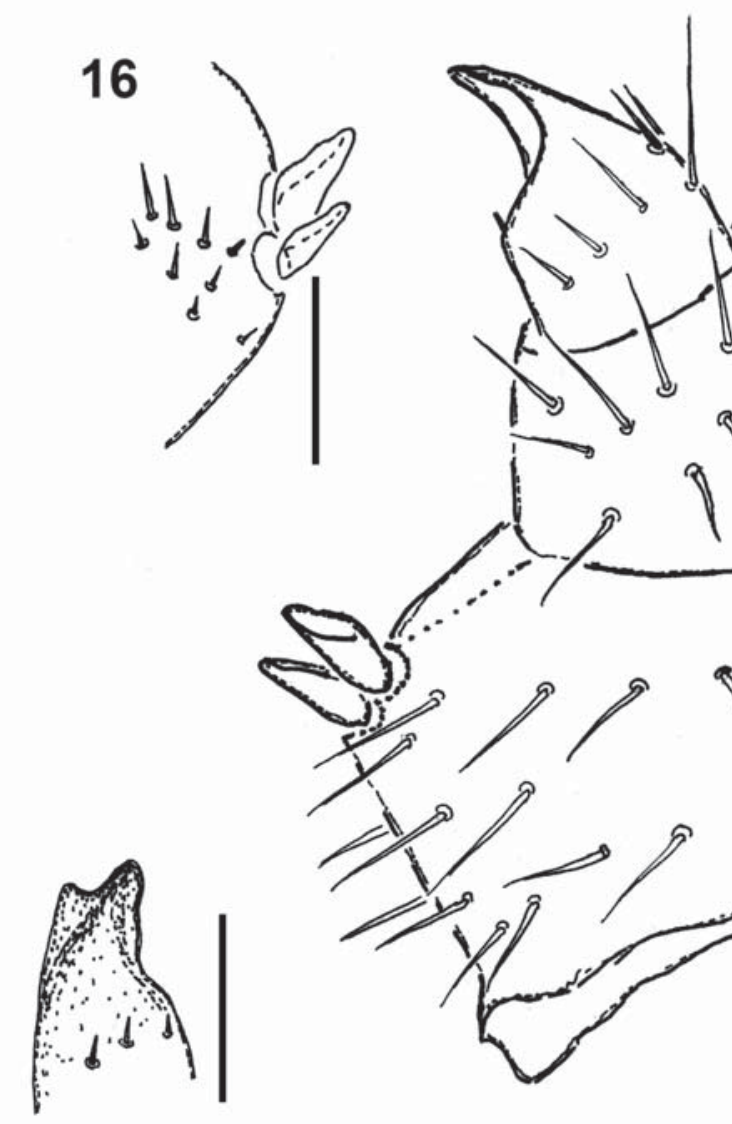

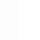




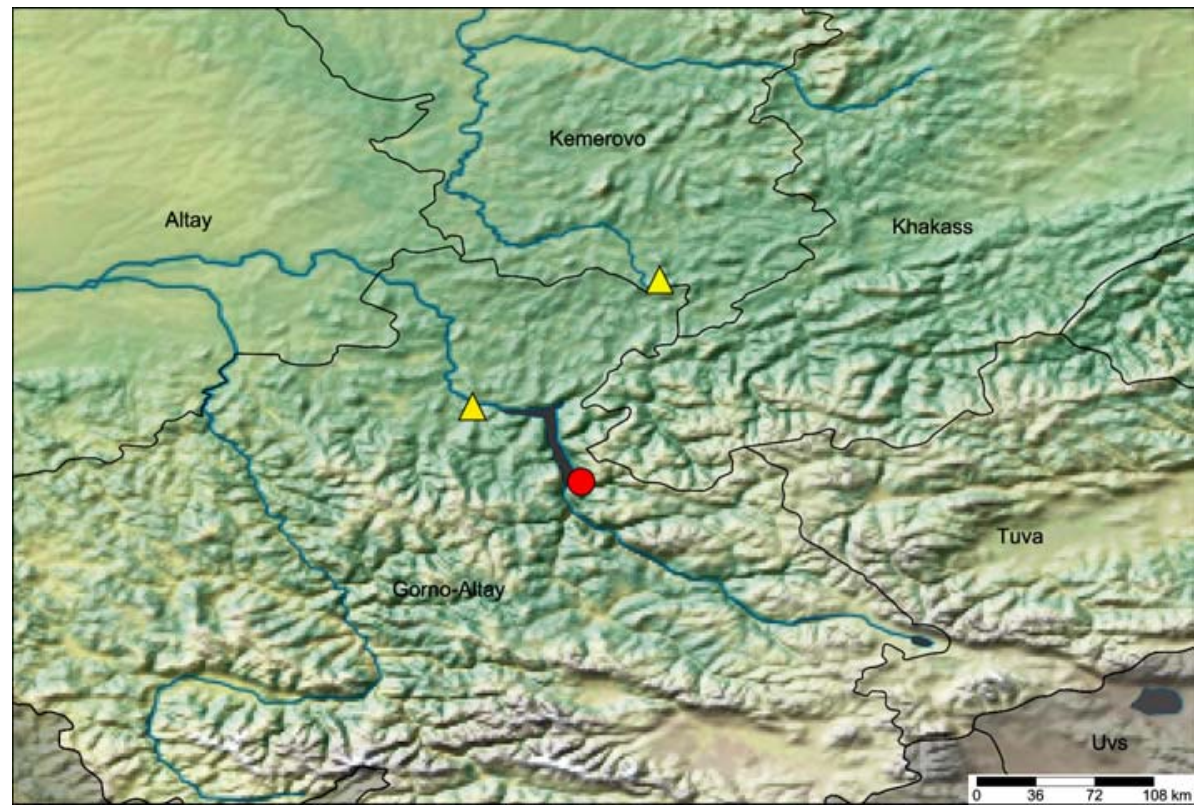

Map 1. Distribution of Lithobius tanagolus sp.n. Red circle indicates the type locality, yellow triangle refers to non-type material.

Карта 1. Распространение Lithobius tanagolus sp.n. Красный круг обозначает типовое местообитание, желтый треугольник - нетиповой материал.

surfaces. Legs 15 with DaC. Accessory spine on leg 15 large, well-developed. Plectrotaxy as in Table. Coxal pores: present on legs $12-15$, large and rounded; inner pores smaller than neighbouring ones; distance between pores varying, but generally not exceeding the diameter of neighboring pore (Fig. 4); formula 3,4,4(5),4(5). Gonopods without setae on internal face, with $2+2$ slender and sharp spurs separated from one another by distances greater than diameter of the widest part of a spur (Fig. 14). First segment of gonopod with one spine, second with 3 , third with one dorsal spine (Fig. 11). Claw of gonopod tridentate, lateral denticles unequal: external lateral denticle displaced to the middle of external ridge (Fig. 13), whereas internal denticle located closer to tip of apical claw (Fig. 12).

Paratype 우. Length 6.3-9.9 mm, breadth 1.0-1.3 $\mathrm{mm}$. All other characters as in holotype, but ocelli 7 11, usually $8-9$ in three rows (Fig. 1). Posterosuperior and posterior ocelli in some specimens slightly larger than seriate ones. Antennomeres varying from 15 to 19, mainly 19+19 antennomeres. Intermediate T either slightly broadened as in holotype or equal in breadth and length. Legs 12 with 3 pores in all specimens, number of coxal pores on legs $13-15$ varying from 3 to 5. Gonopods: second segment usually with 3 dorsal spines (in two specimens second segment with 4 spines on one of gonopod); gonopodal claws tridentate, but in some specimens external lateral denticles poorly-expressed.

Paratype $O^{7} O^{7}$. All characters as in $0+$, but body length $6.5-10.0 \mathrm{~mm}$; intermediate $\mathrm{T}$ slightly elongate or equal in breadth and length. Legs 14 and 15 slightly incrassate, without clearly expressed secondary sexual characters, with glandular pores on lateral and ventral surfaces. Ti 15 in adult $O^{7} O^{7}$ (large and well-sclerotized) with a poorly-developed distodorsal sulcus, the latter never crossing entire Ti (Figs 7-8). In most $\bigcirc^{7} \sigma^{7}$, sulcus visible from half to $2 / 3$ tibia and extending to its distal margin (when viewed from above, the sulcus is poorly visible, as in Fig. 9). In young $0^{7} O^{7}$ (but with developed gonopods) no such sulcus is visible. Plectrotaxy as in holotype, but some specimens with $14 \mathrm{VpF}$. Coxal pores as in holotype, their number varying from 2 to 5 . Gonopods 1-segmented, small and low, with a single seta.

VARIATION. Some specimens show an asymmetric number of antennomeres, ocelli and spinulations on the right and left $q$ gonopods. Thus, the most common situation is a different number of antennomeres on the left and right antennae (usually, one of the antennae consists of 19 antennomeres) and a variable number of ocelli (the difference is usually 1 , rarely 2 ocelli). The structure of the 9 gonopods is relatively stable: in most of the $2^{\text {nd }}$ gonopodal segment is with 3 , rarely 4 dorsal spines (Fig. 11); the claws are three-dentated, and the internal lateral denticle is always well-developed, while the external lateral denticle is shifted from the apex to the middle of the claw and is poorly-expressed in some specimens.

Plectrotaxy is relatively stable, but in some specimens $\mathrm{DaP}$ begin from leg-pair 9 and $\mathrm{VaF}$ from legpair 3.

REMARKS. The new species belongs to the subgenus Monotarsobius, based on the clearly unipartite tarsi of legs 1-13, 19-segmented antennae, the absence of 
posterior triangular projections on the tergites, $2+2$ forcipular coxosternal teeth and setiform porodonts.

Lithobius tanagolus sp.n. show no apomorphies, but differs from other species by a unique combination of characters. Thus, both sexes of L. tanagolus sp.n. differ from all Palaearctic Monotarsobius species by (1) 19-segmented antennae, (2) the large accessory spine on leg $15,(3)$ the usually $8-9$ (rarely $7,10-11$ ) dark ocelli arranged in three rows, (4) the large Tömösváry's organ that is slightly larger than or equal to the neighboring ocellus, (5) $2+2$ acute teeth and (6) the sloping shoulders of the forcipular coxosternite. In addition, +9 have a rare feature, i.e. the dorsal spine on the $1^{\text {st }}$ gonopodal segment. $\sigma^{\top} \sigma^{7}$ are characterized by a poorly-expressed sulcus in the distodorsal part of $15 \mathrm{Ti}$. The sulcus is clearly visible in well-sclerotized mature $\sigma^{7} \sigma^{7}$, but in young $\sigma^{7} \sigma^{7}$ with fully developed gonopods it may be absent.

Lithobius tanagolus sp.n. is especially similar to $L$. (Monotarsobius) holstii (Pocock, 1895), recorded from the Kurile Islands [Eason, 1996], China and Japan [Takakuwa, 1941; Pei et al., 2011], but differs in the sloping shoulders of the forcipular coxosternite (cp. Figs 19 and 20), the number of ocelli (7-11 in $L$. tanagolus sp.n. vs. 5-6, rarely as many as 9 in L. holstii [Eason, 1996], cp. Figs 1 and 25 \& 27), the number of antennomeres (usually, 19 in L. tanagolus sp.n. vs. 20 (our data) or 19-20 (rarely 17 or 21 in L. holstii [Eason, 1996]) and some plectrotaxy details (14 VaTi and $14 \mathrm{DaC}$ in L. holstii vs. without such in L. tanagolus sp.n.). The + of $L$. tanagolus sp.n. differs well from $L$. holstii by (1) the presence of a distodorsal spine on the $1^{\text {st }}$ gonopodal segment (absent in L. holstii) and (2) the armament of the $2^{\text {nd }}$ and $3^{\text {rd }}$ gonopodal segments (cp. Figs 11 and 15). In addition, the + of L. tanagolus sp.n. is devoid both of setae and spines on the inner surface of the $1^{\text {st }}$ gonopodal segment (cp. Figs 14 and 16).

On the other hand, the $O$ of L. tanagolus sp.n. is similar to the $O \bigcirc$ of $L$. (Monotarsobius) insolens Dányi et Tuf, 2012 and L. (Monotarsobius) worogowensis Eason, 1976 by the structure of the gonopod, but differs by the 19-segmented antennae (vs. 20-segmented in L. insolens and L. worogowensis) and plectrotaxy, especially, $15 \mathrm{DaC}$ in the new species vs. 9-15 $\mathrm{DaC}$ in L. insolens and 13-15 in L. worogowensis (for details see [Farzalieva, 2006: 107]).

Finally, L. tanagolus sp.n. is also somewhat similar to further two Lithobius (Monotarsobius), namely, $L$. songi Pei, Ma, Shi, Wu et Zhou, 2011, from Hebei Province, and L. zhangi Ma, Pei, Hou et Zhu, 2014, from Shandong Province, both showing a close body length, 19+19 antennomeres, 2+2 coxosternal teeth, $2+2$ spurs and a tridentate $\rightarrow$ gonopodal claw. However, L. tanagolus sp.n. is well-distinguished from the latter two species by the presence of an accessory spine on leg 15 (leg 15 devoid of such in L. songi and L. zhangi) and 3-5 coxal pores (vs. 1-2 in L. songi and L. zhan$g i)$. In addition, the new species differs from $L$. song $i$ and $L$. zhangi by the number of ocelli ( $8-9$ vs. $6-7$ in $L$. songi and 5-6 ocelli in L. zhangi), the leg plectrotaxy (e.g. $15 \mathrm{DaC}$ in L. tanagolus sp.n. vs. $14-15 \mathrm{DaC}$ in $L$. songi and in L. zhangi; for more details see [Pei et al., 2011; Ma et al., 2014b]), as well as in the presence of a dorsolateral spine on the $q$ first gonopodal segment (absent in L. songi and L. zhangi).

DISTRIBUTION (Map 1). The Altai Republic and Kemerovo Region.

Lithobius (Monotarsobius) holstii Pocock, 1895 Figs 15-18, 20-27, Map 2.

Lithobius holstii Pocock, 1895, 349.

Monotarsobius crassipes holstii: Attems, 1909, 19.

Monotarsobius takakuwai Verhoeff , 1937, 188, 193.

Monotarsobius crassipes holstii: Takakuwa, 1941, 292, fig.1.

Monotarsobius crassipes holstii: Wang, 1959, 198.

Lithobius holstii: Eason, 1973, 75-77, Figs 52-54 (+).

Monotarsobius takakuwai: Zalesskaja, 1978, 184. $13(\stackrel{\circ}{+})$.

Lithobius (Monotarsobius) holstii: Eason, 1996, 121, Figs 12

Lithobius (Monotarsobius) holstii: Ma et al, 2014b, 336, 345.

MATERIAL. $5 \sigma^{\top} \sigma^{\top}, 5$ 우 (PSU), Sakhalin Region, Kunashir Island, Kurilskiy Nature Reserve, $44^{\circ} 05^{\prime} \mathrm{N}, 145^{\circ} 59^{\prime} \mathrm{E}$, Alekhinskiy Cordon, mixed forest, slope with Alnus, 3-4.VII \& 2-6.VIII.1970; $9 \sigma^{7} \sigma^{7}, 6$ 우 (ZMMU), same locality, Tret'yakovo Village, forest $\&$ hot spring, litter, 25-29.VII.1970; 6 ○ $\sigma^{7}, 3$ 우 (ZMMU), same locality, Lake Goryacheye, forest litter, 8.VIII.1970, all leg. A.L. Tikhomirova.

DIAGNOSIS. Body length 9-13 mm, uniformly yellow in alcohol, antennae composed 19-21 articles, commonly $20+20$; 5-6 ocelli on each side, commonly 6 , arranged in two rows; Tömösváry's organ larger than adjoining ocelli; $2+2$ coxosternal teeth; porodonts longer than adjoining tooth; number of coxal pores varying from 3 to 6 , generally 4 ; + gonopods with $2+2$ spurs; $1^{\text {st }}$ gonopodal segment with a group of short setiform spines on internal face, but without dorsolateral spines; $2^{\text {nd }}$ segment with $6-8$ long and stout dorsolateral spines; terminal claw bidentate (tridentate in young +9 ); leg 15 without modifications, but with an accessory spine in both sexes.

DESCRIPTION. See Zalesskaja [1978] and Eason [1996].

REMARKS. The species was sufficiently completely redescribed by Eason [1996], also based on samples from the Kuriles, but some new features of gonopodal structure have become found in females. In particular, an important diagnostic feature that was noted neither in the original description [Pocock, 1895] nor in the redescription [Eason, 1996] is that the $1^{\text {st }}$ gonopodal segment on the inner surface bears a group of short, well distinguishable spines (sometimes the spines are not the same in size, some of them resembling short setae) (Fig. 16). In addition, the dorsal armament of the $q$ gonopod shows the following distinctive features: $1^{\text {st }}$ segment without spines, $2^{\text {nd }}$ one with a group of sharp and powerful, often twinned, rather long spines, their number varying, but always greater than $6 ; 3^{\text {rd }}$ segment with $2-3$ same spines (Figs 15, 18). All specimens examined have a uniformly yellow coloration (Fig. 21, 26-27), legs 15 are densely setose in both sexes (Figs 21, 23). 

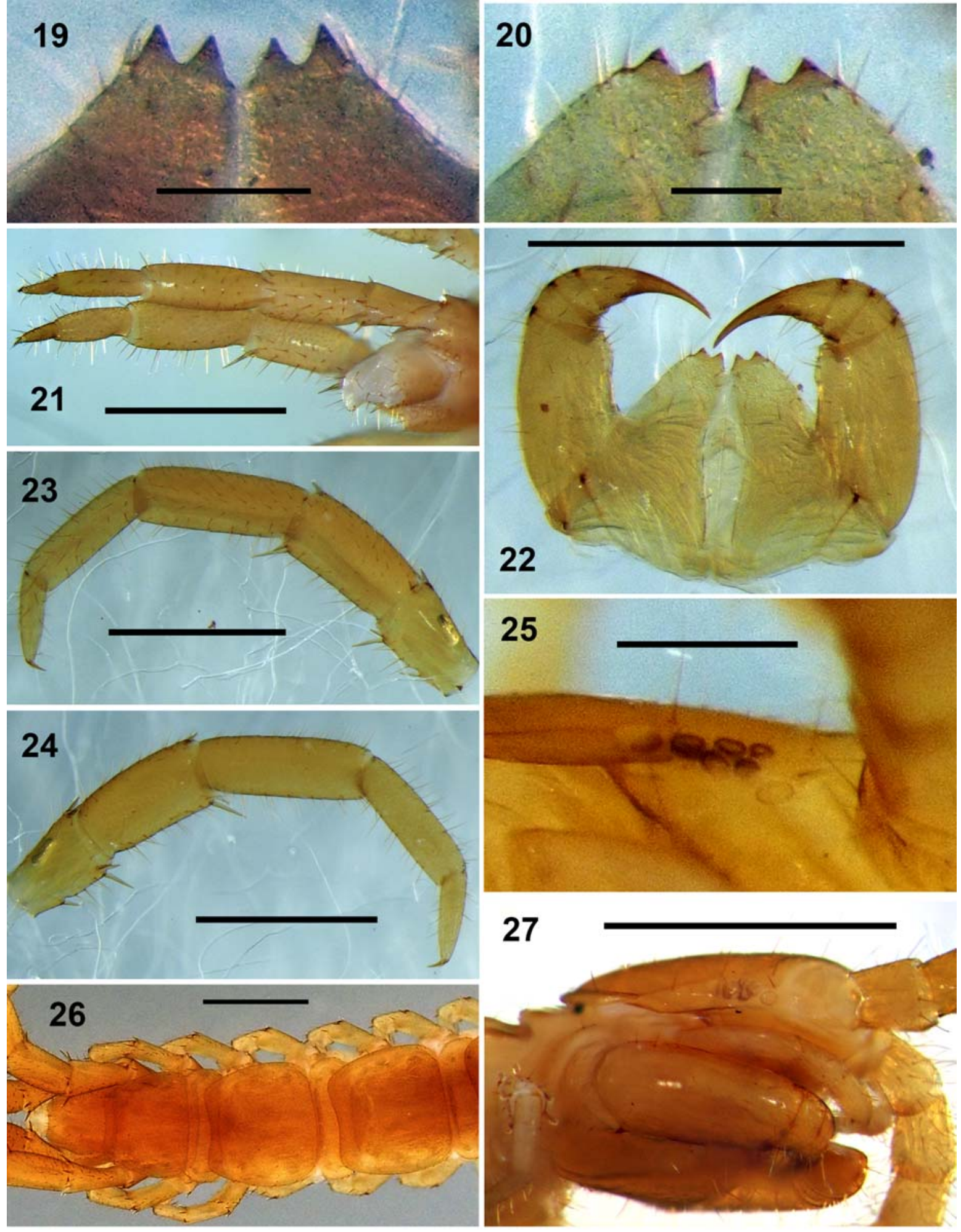

Figs 19-27. Lithobius tanagolus sp.n (non-type) (19) and Lithobius holstii (Pocock, 1895) (20-27). 19-20 - dental margin of forcipular coxosternite; $21-\mathrm{O}^{7}$ rear body fragment, ventrolateral view; $22-$ forcipula, ventral view; $23-24-\mathrm{O}^{7}$ leg 15 , prolateral and retrolateral views, respectively; $25-\sigma^{7}$ ocelli and Tömösváry's organ, lateral view; $26-\bigcirc^{7}$ rare body fragment, dorsally; $27-q$ head, lateral view. Scale: $19-20-0.1 \mathrm{~mm}, 25-0.2 \mathrm{~mm}, 21-24,26-27-1 \mathrm{~mm}$.

Рис. 19-27. Lithobius tanagolus sp.n (нетиповой материал) (19) и Lithobius holstii (Pocock,1895) (20-27). 19-20 - зубной край коксостернита ногочелюсти; 21 — задняя часть тела самца, вентролатерально; 22 - ногочелюсть, вентрально; 23-24 - нога 15 самца, пролатерально и ретролатерально, соответственно; 25 - глазки и орган Темешвари самца, латерально, 26 - задняя часть тела самца, дорсально; 26 - голова самки, латерально. Масштаб: $19-20-0,1$ мм, $25-0,2$ мм, 21-24, 26-27-1 мм. 


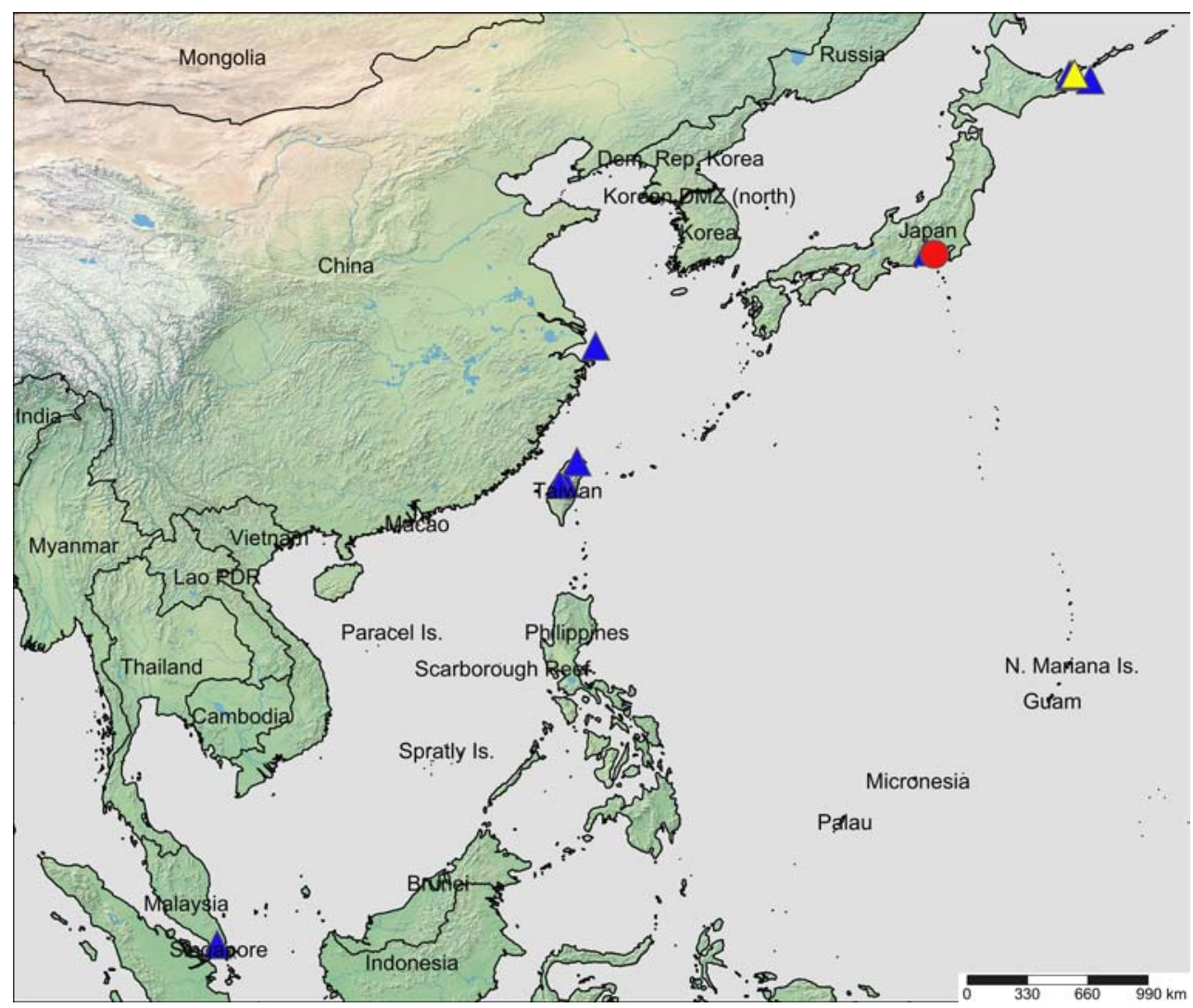

Map 2. Distribution of Lithobius holstii (Pocock, 1895). Red circle indicates the type locality, yellow triangle refers to new data, blue triangle to literature data.

Карта 2. Распространение Lithobius holstii (Pocock,1895). Красный круг обозначает типовое местообитание, желтый треугольник — новые данные, синий треугольник — литературные данные.

DISTRIBUTION (Map 2). The species appears to be distributed along the eastern coast of Asia: from Singapore in the south to Kunashir Island in the north. Ashinoju, Japan $\left(35^{\circ} 14^{\prime} \mathrm{N}, 139^{\circ} 06^{\prime} \mathrm{E}\right)$ (type locality)

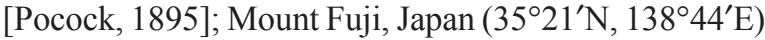
[Attems, 1909]; Puli, Taiwan $\left(23^{\circ} 58^{\prime} \mathrm{N} 120^{\circ} 58^{\prime} \mathrm{E}\right)$ and Taipei, Taiwan $\left(25^{\circ} 02^{\prime} \mathrm{N}, 121^{\circ} 32^{\prime} \mathrm{E}\right)$ [Takakuwa, 1941 ]; Kunashir Island, Kurile Islands, Russia: Yuzhno-Kurilsk $\left(44^{\circ} 02^{\prime} \mathrm{N}, 145^{\circ} 51^{\prime} \mathrm{E}\right)$, Mendeleev Volcano $\left(43^{\circ} 58^{\prime} \mathrm{N}\right.$, $\left.145^{\circ} 44^{\prime} \mathrm{E}\right)$, Lake Aliger $\left(44^{\circ} 2^{\prime} \mathrm{N}, 145^{\circ} 44^{\prime} \mathrm{E}\right)$ and Shikotan Island, Kuriles $\left(43^{\circ} 48^{\prime} \mathrm{N}, 146^{\circ} 45^{\prime} \mathrm{E}\right)$ [Eason, 1996]; Nantou, Taiwan $\left(23^{\circ} 55^{\prime} \mathrm{N}, 120^{\circ} 41^{\prime} \mathrm{E}\right)$ [Wang, 1959]; Shengsi City, Zhejiang Province, China $\left(30^{\circ} 43^{\prime} \mathrm{N}\right.$ $\left.122^{\circ} 27^{\prime} \mathrm{E}\right)$ and Republic of Singapore $\left(1^{\circ} 21^{\prime} \mathrm{N}\right.$, $103^{\circ} 51^{\prime} \mathrm{E}$ ) [Chamberlin, Wang, 1952]; Kunashir Island, Kurilskiy Nature Reserve, Russia $\left(44^{\circ} 05^{\prime} \mathrm{N}\right.$, $145^{\circ} 59^{\prime} \mathrm{E}$ ) (our data).

ACKNOWLEGMENTS. The author wishes to thank S.I. Golovatch (Moscow, Russia) for kindly editing the English of an advanced draft. Special gratitude goes to S.L. Esyunin (Perm, Russia) for his constant guidance, encouragement and support, as well as to Ark.A. Schileyko (Moscow, Russia) and L.A. Trilikauskas (Novosibirsk, Russia) for the provision of material for study.

\section{References}

Attems C.M.T. 1909. Die Myriopoden der Vega-Expedition // Arkiv för zoologi. Bd.5. H.3. S.1-84.

Bonato L., Edgecombe G.D., Lewis J.G.E., Minelli A., Pereira L.A., Shelley R.M., Zapparoli M. 2010. A common terminology for the external anatomy of centipedes (Chilopoda) // ZooKeys. Vol.69. P.17-51. doi: 10.3897/zookeys.69.737.

Bonato L., Edgecombe G.D., Zapparoli M. 2011. Chilopoda Taxonomic overview // Minelli A. (ed.). Treatise on Zoology Anatomy, Taxonomy, Biology. Vol.1. The Myriapoda. LeidenBoston: Brill. P.363-443.

Chamberlin R.V., Wang Y.H.M. 1952. Some records and descriptions of chilopods from Japan and other Oriental areas // Proceedings of the Biological Society of Washington. Vol.65. P.177-188.

Dányi L., Tuf I.H. 2012. Lithobius (Monotarsobius) franciscorum sp. nov., a new lithobiid species from the Altai, with a key to the Central Asian species of the subgenus (Chilopoda: Lithobiomorpha) // Zootaxa. Vol.3182. P.16-28.

Eason E.H. 1973 The type specimens and identity of the species described in the genus Lithobius by R. L. Pocock from 1890 to 1901 (Chilopoda, Lithobiomorpha) // Bulletin of the British Museum, Zoology. No.25. P.41-83.

Eason E.H. 1996. Lithobiomorpha from Sakhalin Island, the Kamchatka Peninsula and the Kurile Islands (Chilopoda) // Arthropoda Selecta. Vol.5. Nos 3/4. P.117-123.

Farzalieva G.Sh. 2006. New species of the lithobiid genus Lithobius (Monotarsobius) (Chilopoda, Lithobiomorpha, Lithobiidae) from eastern Kazakhstan // Arthropoda Selecta. Vol.15. No.2. P.99-117. 
Farzalieva G.Sh., Esyunin S.L. 2008. A review of the centipede (Lithobiomorpha, Henicopidae, Lithobiidae) fauna of the Urals and Cis-Ural Area // Entomological Review. Vol.88, No.5. P.598-623.

Farzalieva G.Sh., Zalesskaja N.T. 2003. On two remarkable species of lithobiid centipedes (Chilopoda: Lithobiomorpha: Lithobiidae) from the steppe of the southern Urals, Russia // Arthropoda Selecta. Vol.11. No.4. P.265-269.

Ma H., Pei S., Hou X., Zhu T., Wu D., Gai Y. 2014a. An annotated checklist of Lithobiomorpha of China // Zootaxa. Vol.3847. No.3. P.333-358. doi: 10.11646/zootaxa.3847.3.2.

Ma H., Pei S., Hou X., Zhu T. 2014b. Lithobius (Monotarsobius) zhangi sp. n., a new species from eastern China (Chilopoda, Lithobiomorpha, Lithobiidae) // Zootaxa. Vol.459. P.1-10. doi: 10.3897/zookeys.459.8169.

Nefediev P.S., Farzalieva G.Sh., Tuf I.H. 2017. A preliminary review of the centipede fauna of the Altai State Nature Biosphere Reserve, southwestern Siberia, Russia (Chilopoda: Lithobiomorpha, Geophilomorpha) // Arthropoda Selecta. Vol.25. No.3. P.257-266.

Pei S., Ma H., Shi B., Wu D., Zhou W. 2011. A new species of Lithobius (Monotarsobius) Verhoeff, 1905 (Lithobiomorpha, Lithobiidae) from China // ZooKeys. Vol.23. No.82. P.59-66. doi: $10.3897 /$ zookeys.82.823.
Pocock R.I. 1895. Report upon the Chilopoda and Diplopoda obtained by P. W. Bassett-Smith Esq. Surgeon R. N. and J. J. Walker Esq. R. N. during the cruise in the Chinese seas of $\mathrm{H}$. M. S. "Penguin" Commander W. U. Moore commanding // Annals and Magazine of Natural History. Ser.6. Vol.15. P.346369.

Takakuwa Y. 1941. Über einige japanische Lithobiiden // Transactions of the Natural History Society of Formosa. Vol.31. P.292298.

Verhoeff K.W. 1937. Chilopoden-Studien. Zur Kenntnis der Lithobiiden // Archiv für Naturgeschichte. N.F. Bd.6. H.2. S.171257.

Wang Y.H.M. 1959. Serica 1j: On Chilopoda from Taiwan with a new lithobiid // Quarterly Journal of the Taiwan Museum. Vol.12. Nos 3-4. P.195-199.

Zalesskaja N.T. 1978. [Identification book of the lithobiomorph centipedes of the USSR]. Moscow: Nauka. 212 p. [in Russian]

Zuev R.V. 2017. Two new species of lithobiid centipedes (Chilopoda: Lithobiomorpha) from the northern Caucasus, Russia // Arthropoda Selecta. Vol.26. No.1. P.15-24.

Responsible editor K.G. Mikhailov 